\title{
A PALYNOLOGICAL STUDY IN GEONOMOID PALMS
}

\author{
W. PUNT AND J. G. WESSELS BOER \\ (Botanical Museum and Herbarium, Utrecht)
}

(received February 28, 1966)

\section{INTRODUCTION}

In a previous palynological study in Cocoid palms the present authors (PUNT and Wessels BoER, 1966) were able to demonstrate a rather strong but not absolute correlation between the pollen types and the staminate flower types within the genus Attalea in the broad sense. The existence of partly apparently primitive, partly very advanced flower types within the otherwise close related group of Geonomoid palms made it worthwhile to investigate the same feature in this group.

The Geonomoid palms are usually considered to comprise 7-9 genera of monoecious Arecoid palms which share a large number of characteristics (Burret, 1930; MoORE, 1966). The group is very obviously a most natural one. The generic distinctions are mainly based on the flower morphology, notably on differences found in the androeceum and pistil.

Staminate palm flowers in general have most frequently 2 whorls of 3 stamens, rarely 1 whorl is lacking or, more frequently, a larger number of stamens or many stamens are present. Usually the anthers consist of 2 lengthwise connected thecae, sagittate at base, dorsifixed and erect in bud. Sometimes rather far derived forms occur. The complete series is observed within the Geonomoid palms. Welfia and Aristeyera have many stamens per male flower (about 20-40); Calyptrogyne, Calyptronoma, Pholidostachys, Asterogyne, Geonoma, and Taenianthera have 6 stamens; Kalbreyera has only 3 stamens. Also the shape of the stamens differs much in the different genera. Welfia, as well as Calyptrogyne, Calyptronoma, and Pholidostachys have the above described dorsifixed sagittate anthers erect in bud (Fig. 1). A more unusual type of stamens occurs in Asterogyne, Kalbreyera, and Geonoma. These genera have stamens with separate thecae born on a bifurcate connective and forming, also at anthesis, a sharp angle with the filament (Fig. 2). This stamen type can be derived from the normal type by a hypothetical reduction of the upper part of the thecae (Fig. 3). The bifid connective is again much more developed in Aristeyera and Taenianthera, bearing separate thecae at its terminal end. This connective with the thecae is inflexed in bud and becomes erect, in line with the filament, at anthesis (Fig. 4).

The pistil of palms in general consists usually of 3 free or more or less united carpels. Also in Geonomoid palms a 3-celled ovary with a terminal style having 3 recurved style branches is found in most genera (Fig. 5). Geonoma and Taenianthera, however, form an exception. 


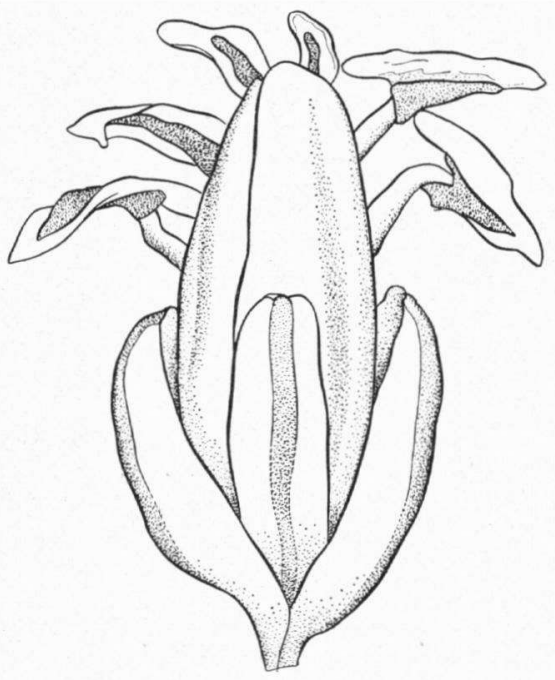

a

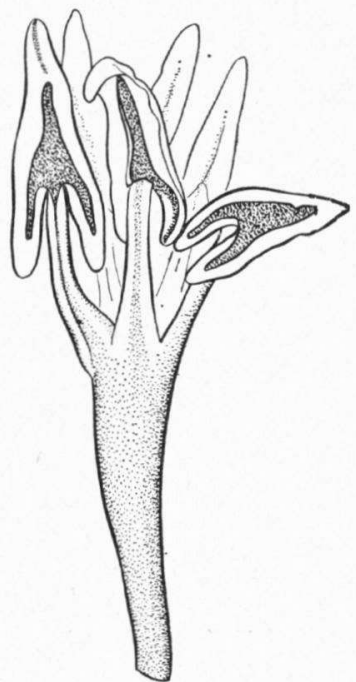

b

Fig. 1. Calyptronoma occidentalis

a. staminate flower; b. androeceum (Ekman H15685, Hispaniola).

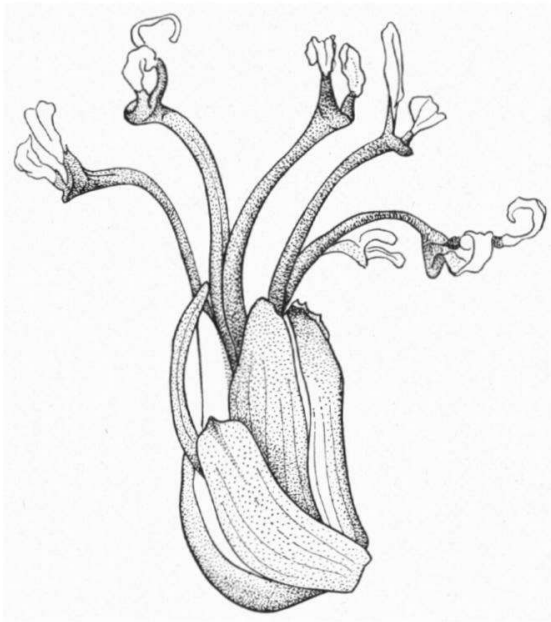

Fig. 2. Geonoma baculifera

Staminate flower (Killip 37437, Venezuela).

These genera have, by reduction of 2 locules, a 1-celled ovary with a basifixed style ending in 3 recurved style branches (Fig. 6). Also the degree of fusion of the staminodes in the pistillate flowers shows some variation. In most genera the staminodes are more or less connate at the base and free in the upper part (Fig. 5). In Kalbreyera and the majority of Geonoma species, the subgenus Eugeonoma of Burret, the 

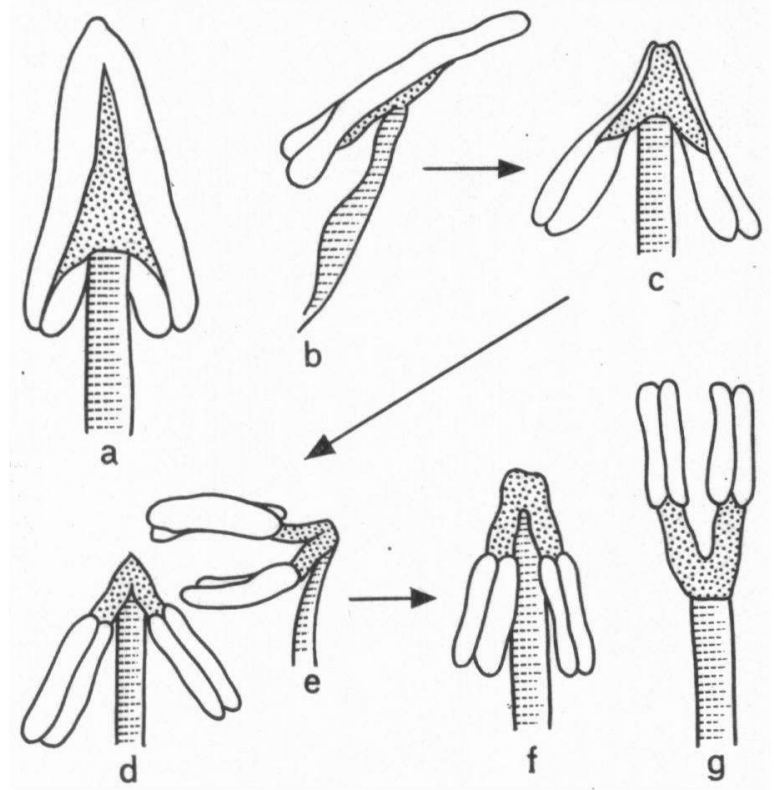

Fig. 3.

Scheme of the series of stamen types. $a$ and $b$. Welfia type; $c$. theoretical intermediate; d. and e. Geonoma type; f. and g. Taenianthera type.

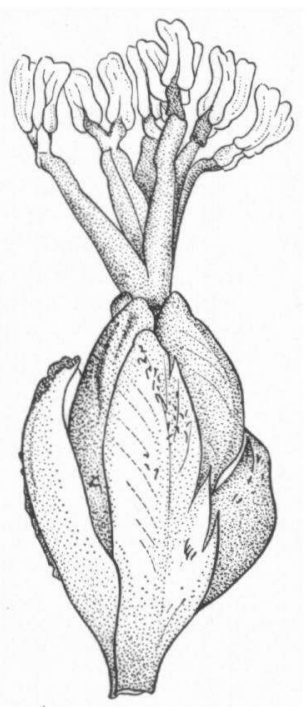

Fig. 4. Geonoma (= Taenianthera) poiteauana. Staminate flower (Hulk 284, Suriname). 


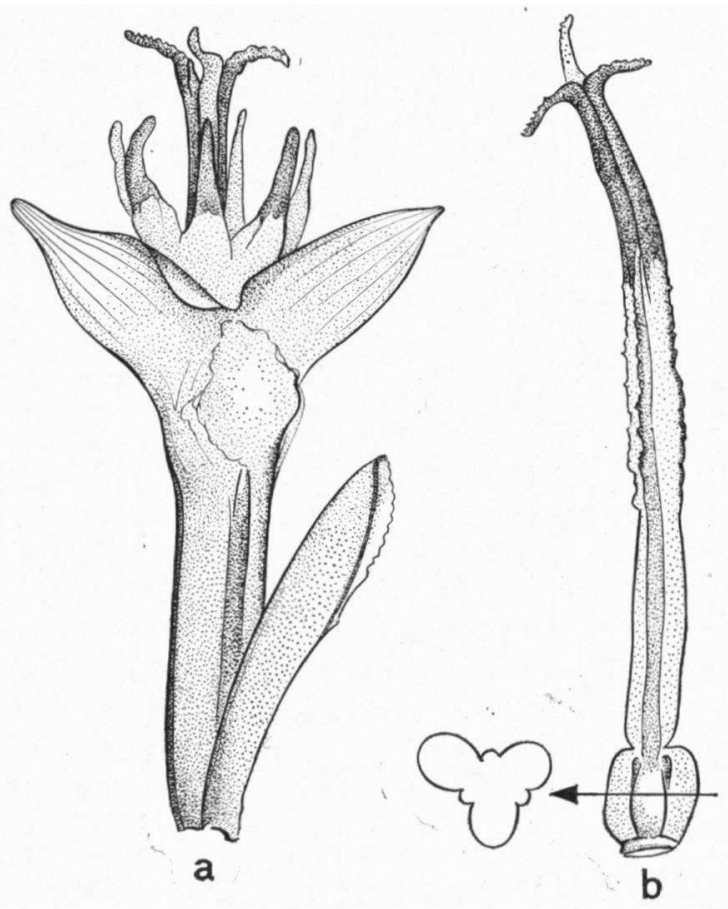

Fig. 5. Asterogyne martiana

a. pistillate flower; b. pistil (Englesing 350, Nicaragua).

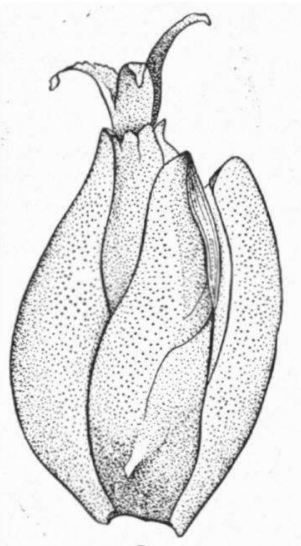

a

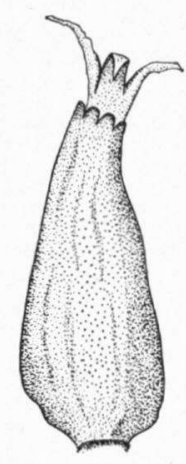

b

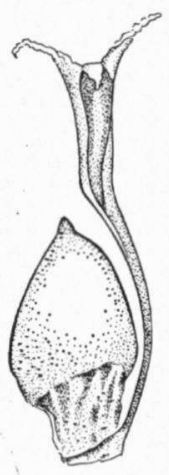

C

Fig. 6. Geonoma simplicifrons

a. pistillate flower; b. staminodial tube enclosing pistil; c. pistil (Killip and Lasser 37802, Venezuela). 
staminodes are almost completely connate forming a truncate or slightly crenulate staminodial tube (Fig. 6).

The occurrence of the different flower characteristics in the separate genera is visualized in the next scheme.

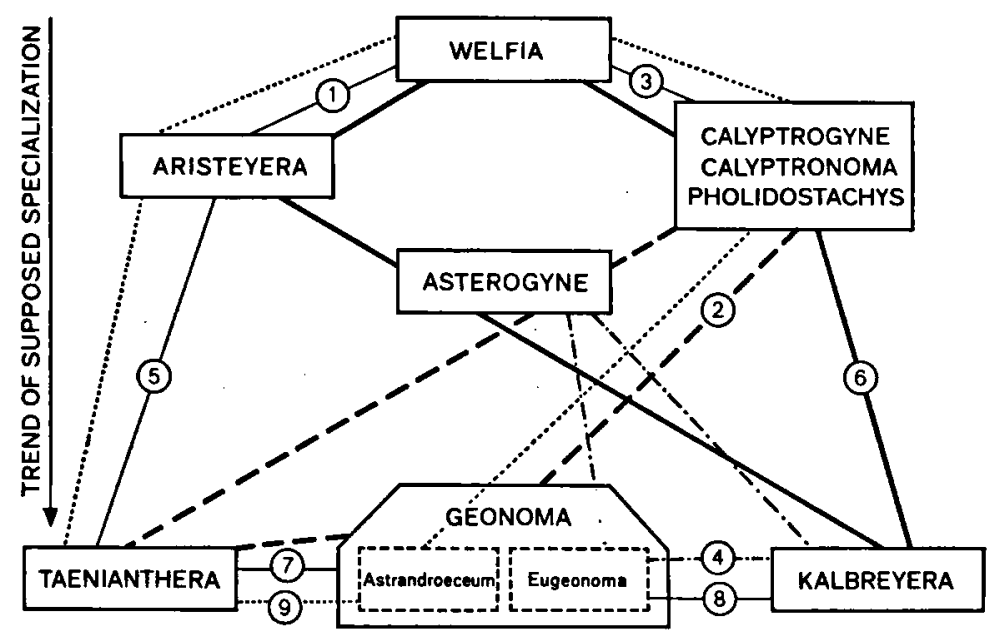

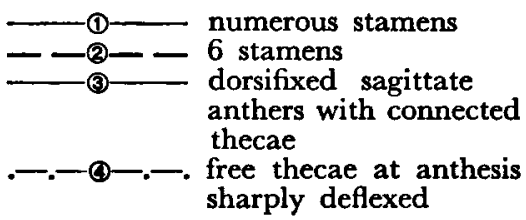

The genus Kalbreyera was founded on a single Kalbreyer collection and never found again. As the type specimen got lost during war-time at Berlin the genus could not be investigated in the present study.

The herbarium material used for this study was mostly obtained from the Utrecht Botanical Museum and Herbarium, and from sheets, which the second author has on loan from several other herbaria. The treatment of the pollen grains was according to the method described by ERDTMAN in 1960. Descriptions have been made with the aid of a Leitz Ortholux microscope, apochr., obj. $\times 63, \times 90$ and an eyepiece $\times 10$. Photographs were made with the same microscope and lenses. The same terminology was used as in the previous study of palm pollen grains (PUNT and Wessels Boer, 1966). 
W. PUNT AND J. G. WESSELS BOER: A palynological study in geonomoid palms
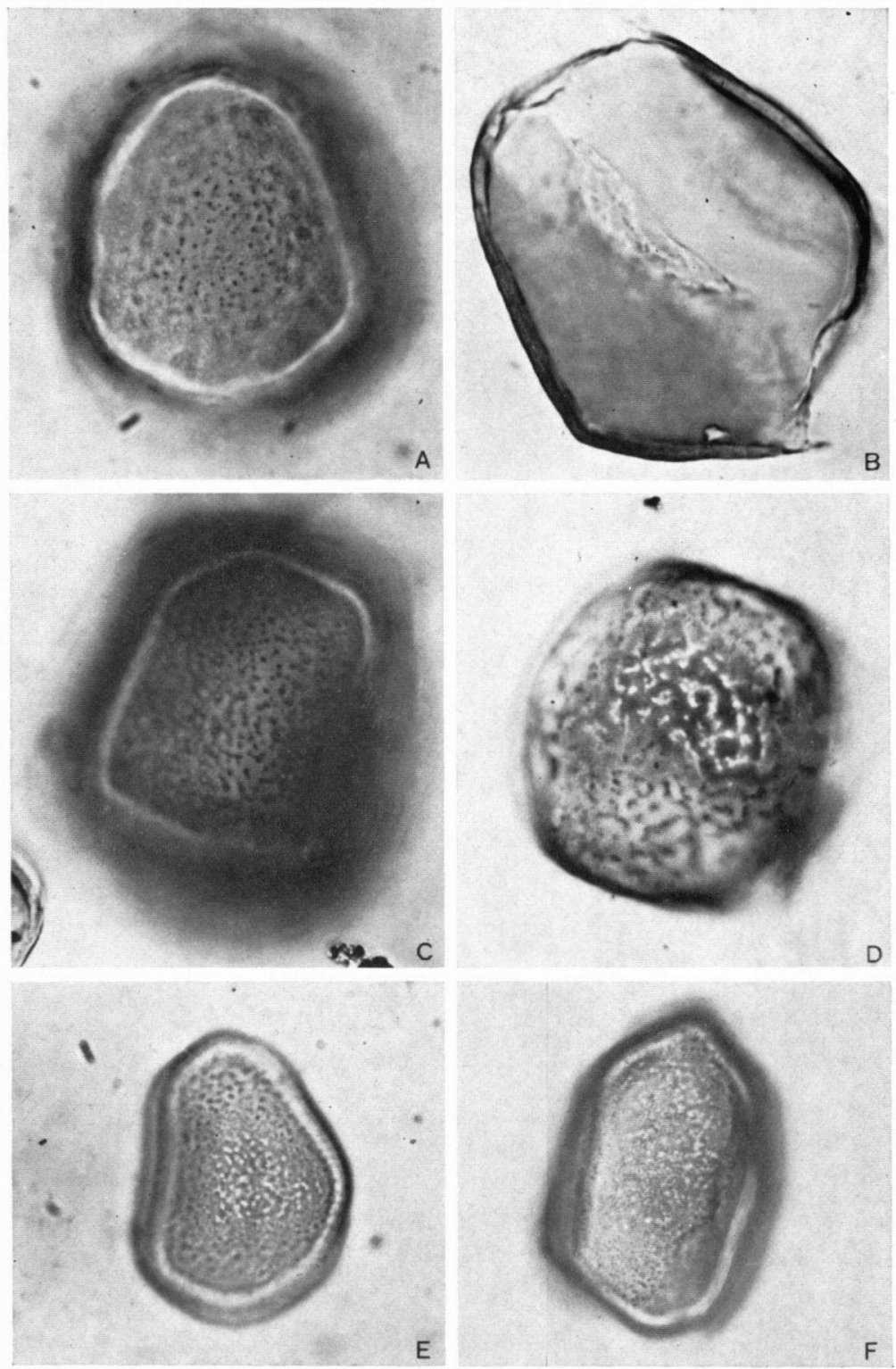

A. and B. Calyptrogyne donnell-smithii; A. surface pattern at proximal pole, B. optical section. C. Calyptronoma clementis; surface pattern at proximal pole. D. Calyptronoma occidentalis; surface pattern at proximal pole. E. Taenianthera tamandua; surface pattern at proximal pole. F. Geonoma poiteauana; surface pattern at proximal pole.

PLATE I 

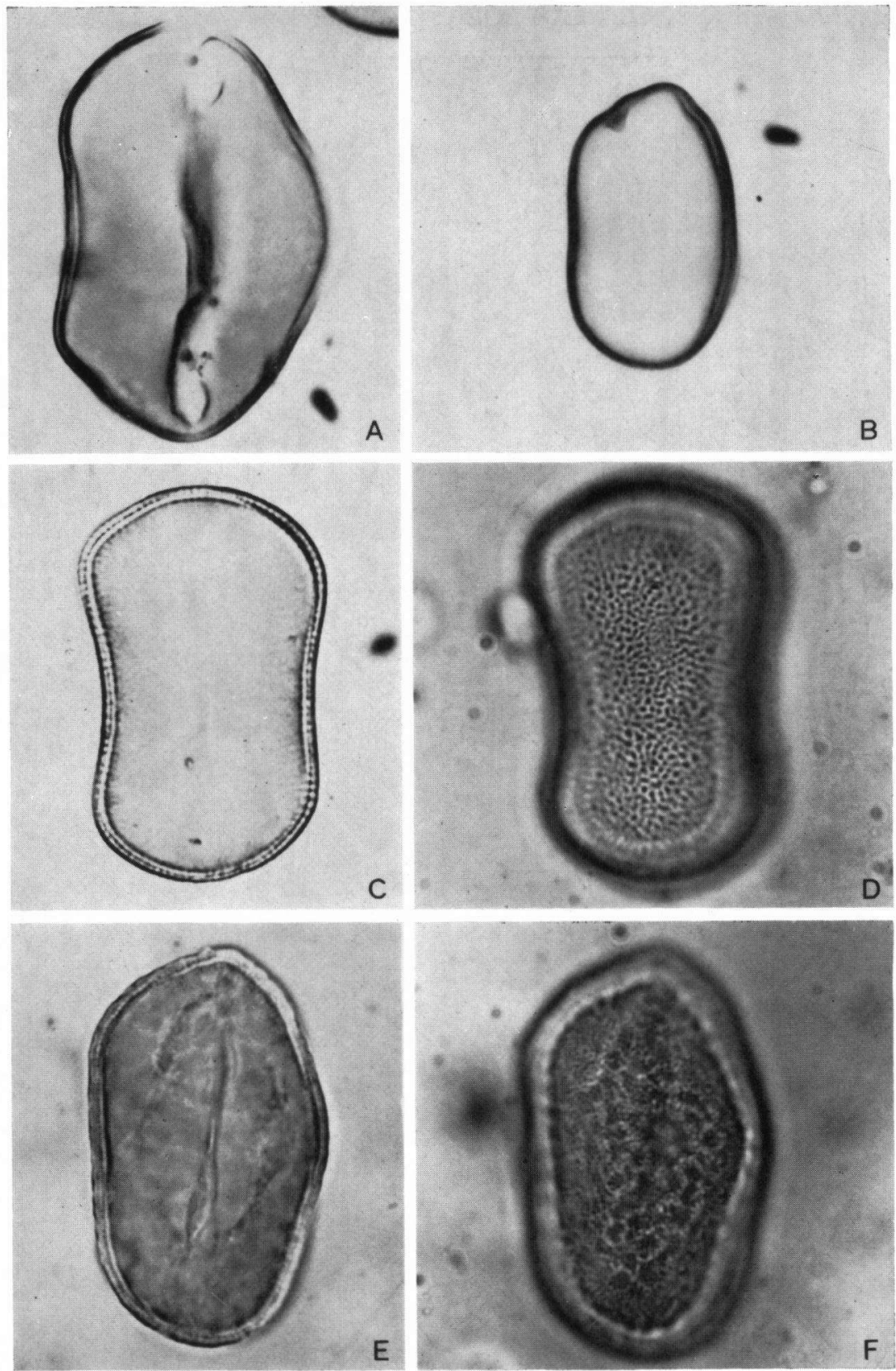

A. Welfia georgii; optical section. B. Geonoma schottiana; optical section. C. and D. Astrogyne martiana; C. optical section, D. surface pattern at proximal pole. E. and F. Pholidostachys pulchra; E. optical section, F. surface pattern at proximal pole. 


\section{Description OF THE MATERIAL}

In the Geonomoid palms the pollen grains do not have many distinctive characters. The grains are always monocolpate. In this respect they differ from the Cocoid palms, in which several species have a mixture of monocolpate and trichotomocolpate grains. The shape of the grains is usually slightly asymmetric, although there are some species having pollen grains which are nearly symmetric. Usually the longest axis of the grains, which follows the colpus, is distinctly larger than the diameter perpendicular on this axis. This diameter is largest when the pollen grains are observed from the distal or from the proximal view. In some pollen types (Calyptrogyne glauca type) the ratio between the two axes is nearly equal.

It is possible to group species into pollen types largely differentiated from one another on the basis of the exine characters. As was found in the Cocoid pollen grains the Geonomoid pollen grains show transitions from one type to another. The Geonoma type seems to be the basic type from which all other types can be derived. Several series of pollen variation can be constructed. One series can be made from small grains to large ones (e.g. Geonoma schottiana and allied forms $\rightarrow$ Welfia spec.). Another series is from thin exine without structure to thicker exine with distinct structure. This thickness is caused by the larger columellae and capita. Two types of structure can be distinguished:

1. Reticulate structure (Asterogyne type)

2. Vermiculate structure (Calyptronoma occidentalis type)

\section{Geonoma type}

Pollen grains monocolpate. Shape of the grains slightly irregular; the longest axis usually distinctly larger than the largest breadth. Sometimes the ratio between the axes is nearly equal. Grains usually between 30 and $40 \mu$. In $W$ elfia the grains are larger.

Exine thin. Sexine (ektexine) thicker than nexine (endexine). Columellae usually indistinct. Most species have indistinct capita. Some species have capita which are more or less visible (Geonoma stricta, G. piscicauda).

To this type belong Geonoma baculifera, G. deversa, G. interrupta, G. leptospadix, G. maxima, G. piscicauda, G. pohliana, G. schottiana, G. stricta, G. umbraculiformis, G. undata, Calyptronoma kalbreyeri, Calyptronoma synanthera, Welfia georgii, and W. regia.

? Geonoma poiteauana and Taenianthera tamandua.

The Geonoma type is a type with rather indistinct characters. The pollen grains are rather small, the shape is slightly asymmetric with one usually noticeably longer axis and an exine without a distinct structure. In this basic type, however, some species are transitional in that they have certain characters typical of the types with a distinct ornamentation.

A. The Welfia species have pollen grains which are larger than those of the other species in the Geonoma type.

B. Some species have pollen with more distinct capita (e.g. Geonoma 
deversa, G. piscicauda, Calyptronoma kalbreyeri). The pollen grains of Geonoma stricta have distinct capita and rather large columellae.

C. In Geonoma umbraculiformis the pollen grains have a rather thick exine (ca $2 \mu$ ) and the tectum is distinctly perforated. In this respect this species is transitional to Geonoma poiteauana and Taenianthera tamandua and also to the Calyptrogyne glauca type.

D. The pollen grains of Geonoma poiteauana and Taenianthera tamandua seem to be transitional to the Asterogyne type.

\section{'Asterogyne type}

Pollen grains monocolpate. Shape only slightly asymmetric. Longest axis distinctly longer than the greatest breadth. Grains rather large; ca $45 \mu$. Exine rather thin. Sexine (ektexine) thicker than nexine (endexine). Grains finely, but distinctly reticulate. Columellae distinct. Lumina small; ca $1 \mu$, muri simplibaculate.

Asterogyne martiana, Taenianthera acaulis.

Geonoma poiteauana and Taenianthera tamandua are transitions to the Geonoma type.

The Asterogyne type can easily be recognised by its fine, but distinct reticulum. The muri (bacula) forming this reticulum are distinctly visible.

Geonoma poiteauana and Taenianthera tamandua have pollen grains which are very similar in most characters. However, the perforations in the Taenianthera species are larger than in the Geonoma species.

The pollen grains of these species are transitional between the Geonoma type and the Asterogyne type. The columellae are indistinct which character is in accordance with that in the Geonoma type. The distinct capita and large perforations in the tectum are characters which occur in the Asterogyne type. On the other hand the perforations are too small to call them a reticulum.

There is also a possibility that Geonoma poiteauana is a transition to the Calyptrogyne glauca type. The tectum perforatum is a character which occurs in this type too, but the shape of the grains is more in accordance with the Geonoma and Asterogyne types.

\section{Calyptrogyne glauca type}

Pollen grains monocolpate. Shape of the grains slightly asymmetric, more or less spheroidal. Longest axis slightly longer than the greatest breadth. Grains rather large; at least $40 \mu$. Exine thick. Sexine (ektexine) thicker than nexine (endexine). Tectum thick, slightly undulating. Perforations present in the tectum. These perforations inordinate arranged or sometimes in very short chains. Capita indistinct, columellae indistinct.

Calyptronoma clementis, Calyptronoma intermedia, Calyptrogyne donnell-smithii, Calyptrogyne glauca, Calyptrogyne trichostachys.

The type is characterised by the thick, slightly undulating tectum; by the inordinate arrangement of the perforations in the tectum and by its shape. 


\section{Calyptronoma occidentalis type.}

Pollen grains monocolpate. Longest axis larger than the greatest breadth. Grains rather large; at least $40 \mu$. Exine thick. Sexine (ektexine) thicker than nexine (endexine). Tectum thick, distinctly undulating. Perforations in the tectum arranged in chains. Ornamentation "vermiculate". Capita and columellae indistinct.

Calyptronoma occidentalis, Calyptrogyne brachystachys, Pholidostachys pulchra, Aristeyera spicata.

This type is characterised by its vermiculate ornamentation. Although Pholidostachy spulchra differs from the other three species in this type by the shape and largeness of the grains, the vermiculate ornamentation is so distinct, that it seems better to place the species in this type.

\section{LIST OF INVESTIGATED SPECIES}

Aristeyera spicata H. E. Moore

Tamayo 4177

Calyptronoma occidentalis type. Longest axis ca $50 \mu$. Exine ca 2,5 $\mu$.

Asterogyne martiana (Wendl.) Wendl. [Plate II C, D]

Archer 1978

Schipp 392

Asterogyne type. Longest axis ca $45 \mu$. Exine ca $2 \mu$. Lumina of the reticulum ca $1 \mu$.

Calyptrogyne brachystachys Wendl. ex Burret

Standley et Valerio 44775 (US) Calyptronoma occidentalis type. Longest axis ca $55 \mu$. Exine ca 2,5 $\mu$. Perforations rather few in short chains, nearly inordinate.

Calyptrogyne donnell-smithii (Dammer) Burret [Plate I A, B]

H. Johnson 1135

Calyptrogyne glauca type. Longest axis ca $60 \mu$. Exine ca 2,5 u.

Calyptrogyne glauca (Oerst.) Wendl. Pittier 4305

Calyptrogyne glauca type. Longest axis ca $55 \mu$. Exine ca $2 \mu$.

Calyptrogyne trichostachys Burret

Stork $1171 / 2$

Calyptrogyne glauca type. Longest axis ca $60 \mu$. Exine ca $1,5 \mu$.

Calyptronoma clementis (León) A. D. Hawkes [Plate I G]

Wright 1466

Calyptrogyne glauca type. Longest axis ca $40 \mu$. Exine ca $2 \mu$.

Calyptronoma intermedia (Griseb. et Wendl.) Wendl. Wright 3972

Calyptrogyne glauca type. Longest axis ca $40 \mu$. Exine ca $2 \mu$.

Calyptronoma kalbreyeri (Burret) Bailey $\quad$ Killip et Smith 15314

Geonoma type. Longest axis ca $35 \mu$. Exine ca 1,5 $\mu$. Capita distinct.

Calyptronoma occidentalis (Sw.) H. E. Moore [Plate I D]

Wessels Boer 1662

Galyptronoma occidentalis type. Longest axis ca $50 \mu$. Exine ca $3 \mu$.Perforations distinctly in chains.

Calyptronoma synanthera (Mart.) Bailey Geonoma type. Longest axis ca $38 \mu$. Exine ca $1 \mu$.

Geonoma baculifera (Poiteau) Kunth Geonoma type. Longest axis ca

Geonoma deversa (Poiteau) Kunth

Wessels Boer 325

Wessels

Wessels Boer 320

Geonoma type. Longest axis ca $30 \mu$. Exine $1-1,5 \mu$. Capita visible.

Geonoma interrupta (Ruiz et Pavon) Mart. Wessels Boer 1635 Geonoma type. Longest axis ca $30 \mu$. Exine ca $1 \mu$.

Geonoma leptospadix Trail Wessels Boer 912 Geonoma type. Pollen grains not quite mature.

Geonoma maxima (Poiteau) Kunth Geonoma type. Longest axis ca $30 \mu$. Exine ca $1 \mu$

Geonoma piscicauda Dammer

Wessels Boer 1617 
Geonoma type. Longest axis ca $45 \mu$. Exine ca 1,5 $\mu$. Capita rather distinct. Geonoma pohliana Mart. Geonoma type. Longest axis ca $35 \mu$. Exine $1-1,5 \mu$.

Geonoma poiteauana Kunth [Plate I F] Wessels Boer 1579

(HBR)

Asterogyne type. Longest axis ca $40 \mu$. Exine $1,5 \mu$. Rather thick tectum with distinct perforations, which are so large that it is a transition to a reticulum. Geonoma schottiana Mart. [Plate II B] Reitz et Klein 9655 Foster 2503

(HBR)

Geonoma type. Longest axis ca $30 \mu$ in Reitz et Klein specimen and $38 \mu$ in the Foster specimen (ERDTMan, 1952). Exine ca $1 \mu$.

Geonoma stricta (Poiteau) Kunth Wessels Boer 1558

Geonoma type. Longest axis ca $40 \mu$. Exine ca 1,5 $\mu$. Capita and collumellae rather distinct.

Geonoma umbraculiformis Wessels Boer

Versteeg 322

Geonoma type. Longest axis ca $40 \mu$. Exine thick; ca $2 \mu$. Capita distinct. Perforations in the tectum inordinate arranged. Transition to the pollen of Geonoma poiteauana.

Geonoma undata Klotzsch Linden s.n.

Geonoma type. Longest axis ca $35 \mu$. Exine ca $1 \mu$.

Pholidostachys pulchra Wendl. ex Burret [Plate II E, F] Standley et Valerio 48937

Calyptronoma occidentalis type. Longest axis ca $40 \mu$. Exine ca $1,5 \mu$.

Taenianthera acaulis (Mart.) Burret Ule 5594

Asterogyne type. Longest axis ca $45 \mu$. Exine 1,5-2 $\mu$.

Taenianthera tamandua (Trail) Burret [Plate I E] Benoist 1708

Geonoma type or Asterogyne type. Longest axis ca $45 \mu$. Exine ca 1,5 $\mu$. Perforations in tectum larger than in Geonoma poiteauana.

Transition between the Geonoma type and the Asterogyne type.

Welfia georgii Wendl. ex Burret [Plate II A] Wendland s.n. Geonoma type. Longest axis ca $45 \mu$. Exine ca $1,5 \mu$.

Welfia regia Wendl. Cuatrecasas 16932

Geonoma type. Longest axis ca $55 \mu$. Exine ca $1,5 \mu$.

\section{Discussion}

As may be clear from the introduction, it is hardly possible to detect any correlation with the floral characteristics. In this case pollen morphology proves to be of little help in classification. The flowers as well as the pollen grains of Welfia seem to be less advanced. The apparently highly specialized flowers of Geonoma have pollen of the same type but smaller.

Most remarkable is the situation in the genera Calyptrogyne, Calyptronoma, and Pholidostachys. These genera, all with the same type of flowers, have been separated on the structure of inflorescence and fruit. Here the pollen morphology of the species belonging to these genera proved to be rather heterogeneous. The pollen diversity, however, is in disagreement with the other characteristics. The pollen of Calyptronoma occidentalis and the hardly distinguishable $C$. clementis and $C$. intermedia belong to different types. Furthermore the very closely related $C$. kalbreyeri and $C$. synanthera differ much in their pollen types which are placed in the Geonoma type and the Calyptronoma occidentalis type respectively.

The same holds true for Calyptrogyne: $C$. brachystachys has pollen of the Calyptronoma occidentalis type; pollen of the other investigated species is referred to a Calyptrogyne glauca type. 


\section{REFERENCES}

Burret, M. 1930. Engler Bot. Jahrb. 63: 123-270.

Erdtman, G. 1952. Pollen Morphology and Plant Taxonomy. Angiosperms. Almquist and Wiksell, Stockholm.

1960. The acetolysis method, a revised description. Svensk Bot. Tidskr. 54: 561-564.

Moore, H. E. 1966. Jo. Arnold Arb. 47: 1-8.

Punt, W. and J. G. Wessels Boer. 1966. Acta Bot. Neerl. 15: 255-265. 